\title{
Karyotype and RAPD Analysis of Ipomoea aquatica Samples Collected from Different Industrial Effluent Affected Areas
}

\author{
Kazi Kamrun Nahar and Sheikh Shamimul Alam* \\ Department of Botany, University of Dhaka, Dhaka-1000, Bangladesh
}

Received July 15, 2015; accepted June 3, 2016

\begin{abstract}
Summary Plant samples of Ipomoea aquatica Forssk. commonly growing in and around the industrial effluent affected areas were selected to examine the effect of industrial effluents at the chromosomal and DNA levels. Five different industrial areas such as (i) textile, (ii) pesticide, (iii) tannery, (iv) ceramic, and (v) pharmaceutical were selected for this study. We observed $2 n=30$ chromosomes in all plant samples of Ipomoea aquatica collected from different affected areas similar to control specimens. After comparison with control, the fluorescent karyotypes (CMA and DAPI) showed significant differences among the samples. Fluorescent banding revealed the probable genomic alteration by deletion and tandem duplication. The different plant samples of this species had characteristic RAPD finger printing. Missing DNA fragments in some sample plants (which is present in control plants) may correlate to the deletion of chromosomal parts. Similarly, some new fragments in the samples (which were not found in the control) may correspond to tandem duplication of the chromosomal parts. Therefore, the toxic substances present in the industrial effluents affected the chromosomes and DNA of Ipomoea aquatic grown in and around the above industrial areas.
\end{abstract}

Key words Fluorescent banding, Karyotype, RAPD, Ipomoea aquatica, Industrial effluent.

A number of industries and factories are present in and around Dhaka City, usually situated on the bank of surrounding rivers. Due to lack of a proper waste treatment system, the industrial effluents are drained directly to the rivers and agricultural land. The industries like textile, leather, paint, pesticides, pharmaceuticals laboratories are noteworthy in those areas (DoE 1997). Most of the effluents contain toxic substances and can have a devastating effect on the environment (Chhatwal et al. 1992). Industrial effluents have been found to increase heavy metal load in surrounding agricultural soils (Joardar et al. 2005). Among the heavy metals, arsenic, cadmium, chromium, lead, nickel, etc. are directly hazardous to health (Huq et al. 2007). These metals are taken up by certain plants growing around the industrial affected areas. Ipomoea aquatica is a popular leafy vegetable growing on this contaminated soil. It has been estimated that this species is able to uptake and accumulate the toxic substances, even faster than other aquatic organisms (Huq et al. 2000). Everyday a huge amount of Ipomoea aquatica come from the various affected areas to the local markets and is sold at cheap price, and a number of people feed on this plant without knowing the sources. In this way, the toxic substances are entering into the human food chain (Ahmed and Reazuddin 2000,

\footnotetext{
* Corresponding author, e-mail: ssalam81@yahoo.com DOI: $10.1508 /$ cytologia. 81.285
}

Huq et al. 2008). Therefore, it is an urgent need to know whether these effluents cause any harm at the chromosomal or DNA level of these plants (Glanze 1996), and if so, whether it will be a threat to human health.

Karyotype analysis is one of the important methods for chromosome study. This method is reliable, stable, and specific for an organism (Nakajima 1963, Hagiwara 1977, Alam et al. 2012, Jahan et al. 2012). A specimen can be identified authentically through karyotype analysis. Moreover, minute alteration regarding the distribution pattern of GC- and AT-rich repeats in the karyotypes could be detected after staining with CMA and DAPI karyotype analysis (Schweizer 1976). With the help of fluorescent banding (CMA and DAPI) a number of chromosomal aberrations was reported earlier (Alam et al. 2012).

Randomly Amplified Polymorphic DNA (RAPD) is a method frequently used for DNA fingerprinting. The term DNA fingerprinting/profiling describes the combined use of several single locus detection systems. This method has been used as a versatile tool for investigating various genomic aspects of an organism (Kennard et al. 1994). Genetic analysis using RAPD markers can provide a powerful approach to understand the organization and distribution of genetic resources in nature and manage populations. A combined approach of fluorescent karyotype and RAPD marker analysis provides sufficient data on the genomic information of organisms 

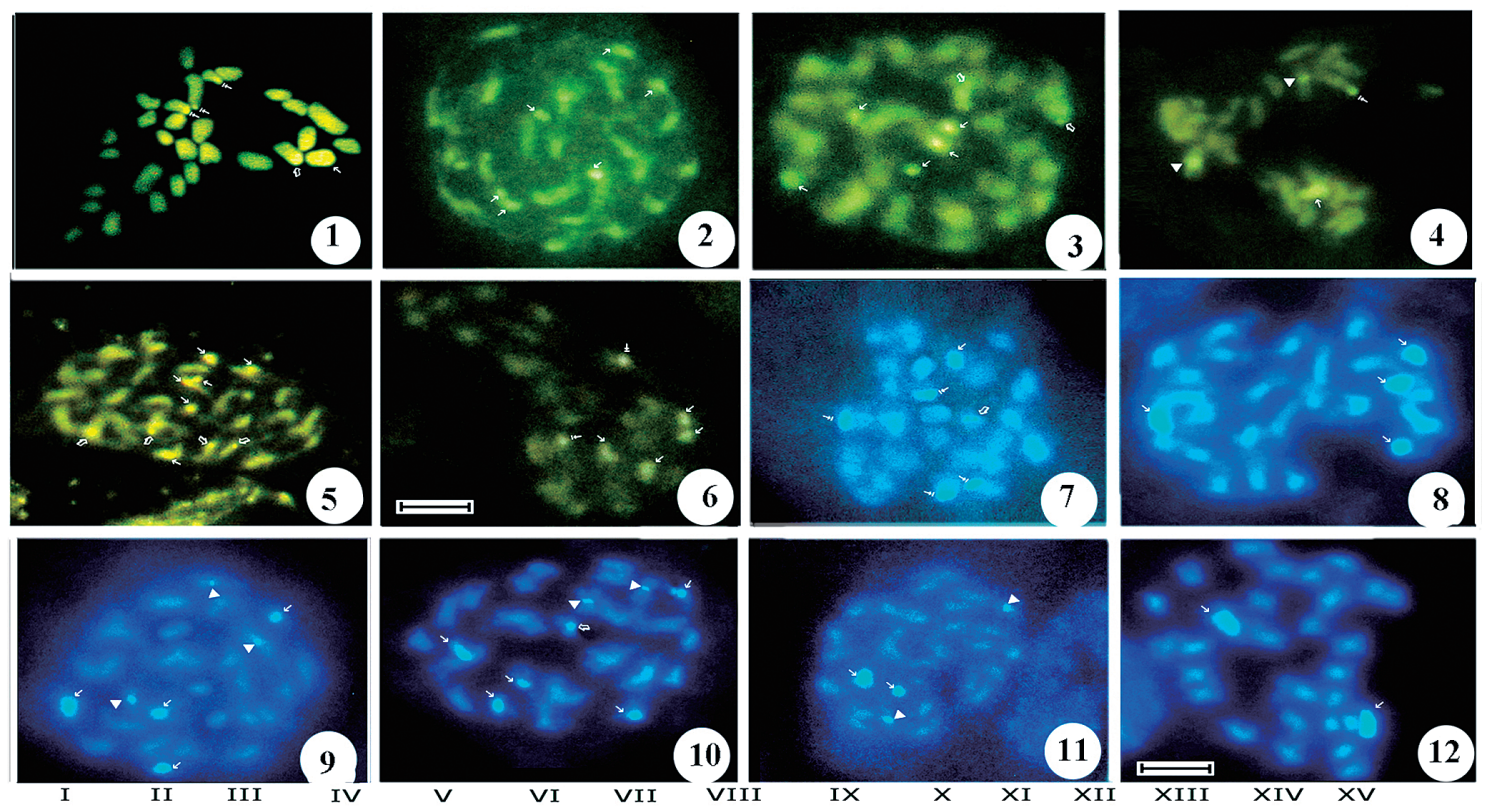

\begin{tabular}{|c|c|c|c|c|c|c|c|c|c|c|c|c|c|c|}
\hline 0 & bo & & & 00 & 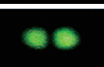 & 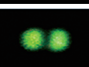 & cos & 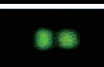 & $=-$ & $\bullet$ & .0 & 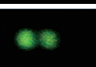 & 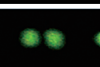 & $\cdots$ \\
\hline 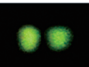 & $80^{g}$ & & 8 & 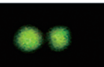 & 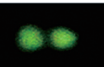 & e & 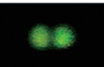 & 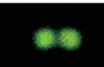 & be & 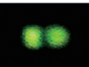 & कह & $\infty$ & wex & 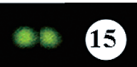 \\
\hline 80 & 01 & 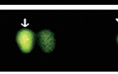 & 7 & A & $\bullet$ & s. & $\bullet$ & $*$ & $\omega$ & $\bullet$ & $\omega$ & 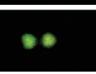 & $*$ & $\cdots$ \\
\hline 6 & et & 80 & 50 & s: & 13 & 8 & 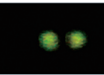 & 88 & 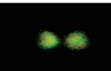 & to & $*$ & 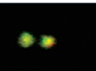 & 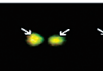 & $=0$ \\
\hline • & (6) & & & "है क्ष & $0 \%$ & & $*$ & $*$ & $\Leftrightarrow$ & . & 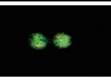 & $\cdots$ & $\ddot{\circ}$ & \\
\hline 30 & 00 & 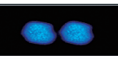 & 00 & 00 & 80 & bó & 00 & 80 & 00 & 80 & 80 & 00 & 00 & $00 \quad 19$ \\
\hline 00 & 80 & 00 & 0 & $\circ 0$ & 00 & 00 & 0 & 00 & 00 & कó & 00 & 00 & $=0$ & $=020$ \\
\hline 08 & 80 & 00 & 80 & ö́ & 0 & $\circ$ & 68 & 0 & $\circ$ & $\infty$ & $\infty$ & 80 & 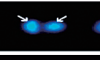 & $\Leftrightarrow 21$ \\
\hline 00 & 00 & עo & $\infty$ & 10 & 58 & 0 & $\infty$ & 00 & $\infty$ & $\infty$ & $00^{\circ}$ & "oú & bó & 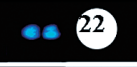 \\
\hline 00 & 00 & 8 & 38 & & & & & 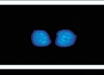 & - & 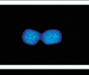 & $=$ & 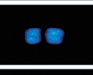 & $+\infty$ & \\
\hline & & & & & & & & & & & & & & \\
\hline
\end{tabular}
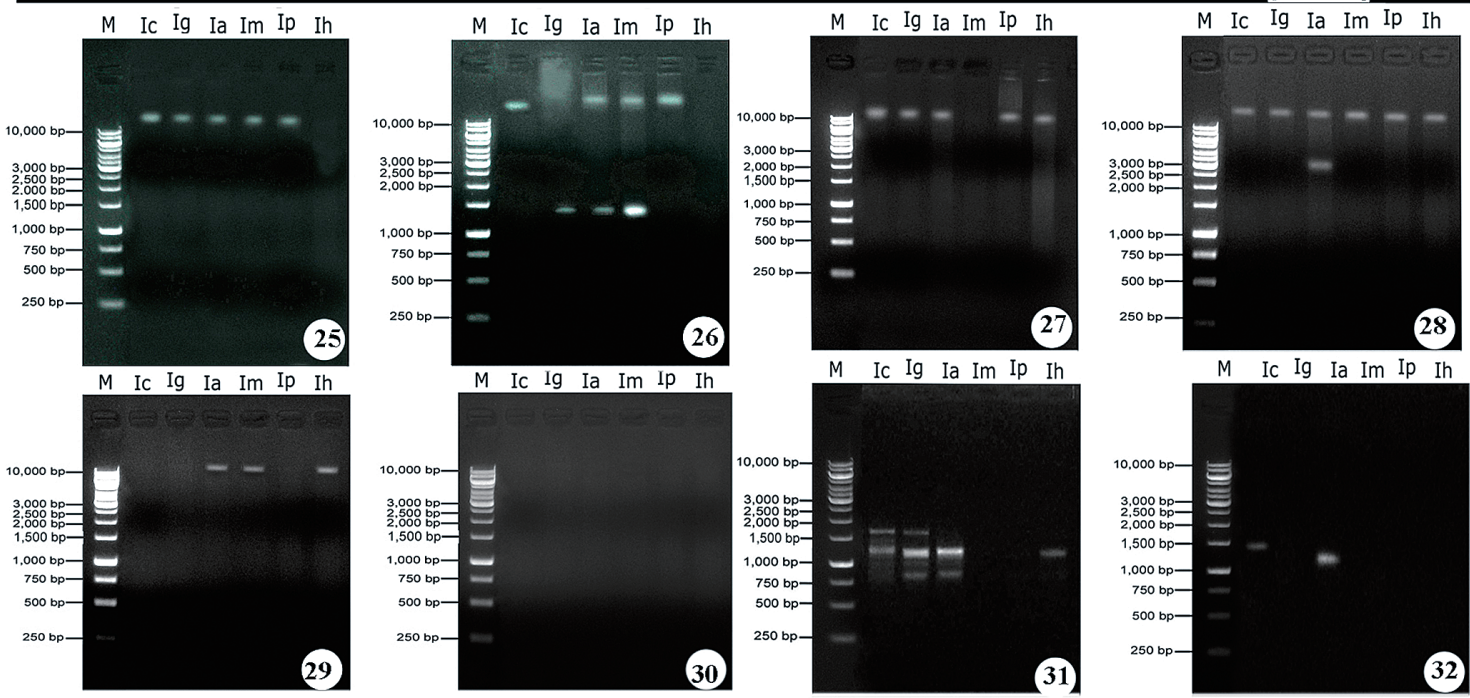
(Alam et al. 2012).

Therefore, the aim of this present research work is to determine whether the industrial effluents have any impact on the chromosomal or molecular level of Ipomoea aquatica by a combination of fluorescent karyotype and RAPD analysis.

\section{Materials and methods}

Ipomoea aquatica Forssk. (convolvulaceae) was used as a sample material in this study because of its wide abundance in and around the industrial affected areas. This plant is a glabrous trailer on mud or floating in water with ovate leaves. The hollow stem and leaves are popular vegetables in Bangladesh. The five different industries selected for this study were: (i) textile: Powertex Fashion Ltd., Gazipur district, (ii) pesticide: Shetu Pesticide Ltd., Savar, (iii) tannery: Salma Leather Industry, Hazaribagh, Dhaka, (iv) ceramic: Monno Ceramic Industries, Nayarhat, Dhamrai, Manikgonj district, and (v) pharmaceutical: Acme Laboratories Ltd., Tulivita, Dhamrai, Manikgonj district. A plant sample was collected as control from the village of Shibrampur, Burichang, Comilla District, which was completely free from any contamination. Both control and sample plants have been maintained in the Botanic Garden, Department of Botany, University of Dhaka.

\section{Cytogenetic study}

Healthy roots were collected and pre-treated with $0.002 \mathrm{M} 8$-hydroxyquinoline for $0.5 \mathrm{~h}$ at room temperature $\left(25-26^{\circ} \mathrm{C}\right)$ followed by fixation in $45 \%$ acetic acid for $5 \mathrm{~m}$ at $4^{\circ} \mathrm{C}$. The root tips were hydrolized for $5 \mathrm{~s}$ at $60^{\circ} \mathrm{C}$ in a solution containing $1 \mathrm{~N} \mathrm{HCl}$ and $45 \%$ acetic acid $(2: 1)$ and stained with $1 \%$ aceto-orcein. For CMA banding, the method used by Alam et al. (1993) was used with slight modification. After hydrolyzing and dissecting, the materials were squashed with $45 \%$ acetic acid. The slides were placed quickly in $-80^{\circ} \mathrm{C}$ freeze for $3 \mathrm{~m}$ and allowed to air dry for at least $24 \mathrm{~h}$ before study. The air-dried slides were first pre-incubated in Mcllvaine's buffer ( $\mathrm{pH}$ 7.0) for 30 min followed by Distamycin A $\left(0.1 \mathrm{mg} \mathrm{mL}^{-1}\right)$ treatment for $10 \mathrm{~min}$. The slides were rinsed mildly in McIlvaine's buffer supplemented with $\mathrm{MgSO}_{4}(5 \mathrm{mM})$ for $15 \mathrm{~min}$. One drop of CMA $\left(0.1 \mathrm{mg} \mathrm{mL}^{-1}\right)$ was added to the material and kept for $15 \mathrm{~min}$ in a humid chamber. The slides were treated again for $10 \mathrm{~min}$ in Mcllvaine's buffer with $\mathrm{MgSO}_{4}$ and 10 min in Mcllvaine's buffer without $\mathrm{MgSO}_{4}$, mounted in $50 \%$ glycerol and kept at $4{ }^{\circ} \mathrm{C}$ for overnight before observation. These were observed under a Nikon (Eclipse 50i) fluorescent microscope with blue violet (BV) filter cassette. For DAPI-staining the method proposed by Alam et al. (1993) was followed after slight modifications. After $48 \mathrm{~h}$ of air drying, the slide was first pre-incubated in Mcllvaine's buffer ( $\mathrm{pH} 7.0$ ) for $30 \mathrm{~min}$. The slide was treated in $0.25 \mathrm{mg} \mathrm{mL}^{-1}$ actinomycin $\mathrm{D}$ for $10 \mathrm{~min}$ in a humid chamber. After antibiotic treatment, the slide was washed with distilled water in such a way that the cover glass was removed. The slide was immersed again in Mcllvaine's buffer ( $\mathrm{pH}$ 7.0) for 15 min followed by treating in DAPI solution $\left(0.1 \mathrm{mg} \mathrm{mL}^{-1}\right)$ for $12 \mathrm{~min}$. After rinsing in McIlvaine's buffer ( $\mathrm{pH}$ 7.0) for $10 \mathrm{~min}$, the slide was mounted with $50 \%$ glycerol and kept at $4{ }^{\circ} \mathrm{C}$. These were observed under a Nikon (Eclipse 50i) fluorescent microscope with ultra violet (UV) filter cassette.

\section{DNA isolation}

Leaves were harvested and total genomic DNA was extracted by using a modified CTAB method (Doyle and

Figs. 1-32. CMA- and DAPI-stained mitotic metaphase and RAPD analysis of six plant samples of Ipomoea aquatica Forssk. collected from five different industrial effluent affected areas and control. 1. CMA-stained mitotic metaphase chromosomes of the control plant. 2. CMA-stained mitotic metaphase chromosomes of the textile effluent affected area sample plant. 3. CMA-stained mitotic metaphase chromosomes of the pesticide effluent affected area sample plant. 4. CMA-stained mitotic metaphase chromosomes of the tannery effluent affected area sample plant. 5. CMA-stained mitotic metaphase chromosomes of the ceramic effluent affected area sample plant. 6. CMA-stained mitotic metaphase chromosomes of the pharmaceutical effluent affected area sample plant. 7. DAPI-stained mitotic metaphase chromosomes of the control plant. 8. DAPI-stained mitotic metaphase chromosomes of the textile effluent affected area sample plant. 9. DAPI-stained mitotic metaphase chromosomes of the pesticide effluent affected area sample plant. 10. DAPI-stained mitotic metaphase chromosomes of the tannery effluent affected area sample plant. 11. DAPI-stained mitotic metaphase chromosomes of the ceramic effluent affected area sample plant. 12. DAPI-stained mitotic metaphase chromosomes of the pharmaceutical effluent affected area sample plant. 13. CMA-karyotype of control plant. 14. CMA-karyotype of the textile area sample plant. 15. CMA-karyotype of the pesticide effluent affected area sample plant. 16. CMA-karyotype of the tannery effluent affected area sample plant. 17. CMA-karyotype of the ceramic effluent affected sample plant. 18. CMA-karyotype of the pharmaceutical effluent affected sample area plant. 19. DAPI-karyotype of the control plant. 20. DAPI-karyotype of the textile effluent affected area sample plant. 21. DAPI-karyotype of the pesticide area plant. 22. DAPI-karyotype of the tannery effluent affected area sample plant. 23. DAPI-karyotype of the ceramic effluent affected area sample plant. 24. DAPIkaryotype of the pharmaceutical effluent affected area sample plant (Bar $=5 \mu \mathrm{m}$ for Figs. 1-24). 25. RAPD analysis with OPA-1. 26. RAPD analysis with OPA-2. 27. RAPD analysis with OPA-3. 28. RAPD analysis with OPA-4. 29. RAPD analysis with OPA-6. 30. RAPD analysis with OPA-8. 31. RAPD analysis with Primer-23. 32. RAPD analysis with Primer-24. $M=1 \mathrm{~kb}$ DNA ladder, Ic=control, Ig=Plant sample collected from the textile waste affected area, Ia $=$ Plant sample collected from the pharmaceutical waste affected area, Im=Plant sample collected from the ceramic waste affected area, I $\mathrm{p}=$ Plant sample collected from the pesticide waste affected area, Ih=Plant sample collected from the tannery waste affected area. 
Table 1. Comparative orcein, CMA- and DAPI-karyotypes in six plant samples of Ipomoea aquatica Forssk. collected from five different affected areas along with control.

\begin{tabular}{|c|c|c|c|c|c|c|c|c|c|}
\hline Plant samples & $2 n$ & $\begin{array}{l}\text { Total length of } \\
2 n \text { chromosome } \\
\text { complement }\end{array}$ & $\begin{array}{l}\text { Karyotype } \\
\text { formulae }\end{array}$ & $\begin{array}{c}\text { No. of } \\
\text { CMA-positive } \\
\text { bands }\end{array}$ & $\begin{array}{l}\% \text { of } \\
\text { GC-rich } \\
\text { repeats }\end{array}$ & $\begin{array}{l}\text { CMA-banded } \\
\text { karyotype } \\
\text { formulae }\end{array}$ & $\begin{array}{c}\text { No. of } \\
\text { DAPI-positive } \\
\text { bands }\end{array}$ & $\begin{array}{l}\% \text { of } \\
\text { AT-rich } \\
\text { repeats }\end{array}$ & $\begin{array}{l}\text { DAPI-banded } \\
\text { karyotype } \\
\text { formulae }\end{array}$ \\
\hline Control & 30 & 47.24 & $30 \mathrm{~m}$ & 5 & 8.93 & $4 \theta+1 \gamma+25 \delta$ & 6 & 9.37 & $4 \theta+1 \psi+1 \gamma+24 \delta$ \\
\hline Textile affected & 30 & 51.24 & $30 \mathrm{~m}$ & 6 & 12.15 & $6 \gamma+24 \delta$ & 4 & 8.41 & $4 \gamma+26 \delta$ \\
\hline Pesticide affected & 30 & 47.66 & $30 \mathrm{~m}$ & 7 & 23.52 & $2 \varphi+5 \gamma+23 \delta$ & 7 & 13.72 & $3 \alpha+4 \gamma+23 \delta$ \\
\hline Tannery affected & 30 & 52.53 & $30 \mathrm{~m}$ & 4 & 8.05 & $1 \theta+1 \gamma+2 \alpha+26 \delta$ & 8 & 11.57 & $3 \alpha+5 \gamma+22 \delta$ \\
\hline Ceramic affected & 30 & 49.88 & $30 \mathrm{~m}$ & 10 & 15.81 & $4 \varphi+6 \gamma+20 \delta$ & 4 & 7.34 & $2 \alpha+2 \gamma+26 \delta$ \\
\hline Pharmaceutical affected & 30 & 61.75 & $30 \mathrm{~m}$ & 6 & 9.02 & $4 \gamma+2 \theta+24 \delta$ & 2 & 4.51 & $2 \gamma+28 \delta$ \\
\hline
\end{tabular}

$\mathrm{m}=$ metacentric chromosome. Classification of CMA and DAPI positive band: $\alpha=$ Band in centromeric region, $\gamma=$ Band in whole chromosome, $\varphi=$ Band in short arm, $\theta=$ Band in terminal region, $\psi=$ Centromeric dot, $\delta=$ No band.

Doyle 1987). DNA concentration was quantified through a spectrophotometer (Analylikjena, Specord 50, Germany). The A 260/280 readings for DNA samples were $1.6-1.8$.

\section{PCR amplification and primer survey}

The PCR reaction mixture for $25 \mu \mathrm{L}$ contained template DNA $(25 \mathrm{ng}) 2 \mu \mathrm{L}$, de-ionized distilled water $18.8 \mu \mathrm{L}$, Taq buffer A $10 \times$ (Tris with $15 \mathrm{mM} \mathrm{MgCl}_{2}$ ) $2.5 \mu \mathrm{L}$, primer $(10 \mu \mathrm{M}) 1.0 \mu \mathrm{L}$, dNTPs $(2.5 \mathrm{mM}) 0.5 \mu \mathrm{L}$ and Taq DNA polymerase $(5 \mathrm{U} / \mu \mathrm{L}) 0.2 \mu \mathrm{L}$. PCR amplification was done in an oil-free thermal cycler (Biometra UNOII, Germany) for 46 cycles after initial denature at $94^{\circ} \mathrm{C}$ for $5 \mathrm{~min}$, denature at $94^{\circ} \mathrm{C}$ for $1 \mathrm{~min}$, annealing at $34-36^{\circ} \mathrm{C}$ for $30 \mathrm{~s}$, extension at $72^{\circ} \mathrm{C}$ for $3 \mathrm{~min}$ and final extension at $72^{\circ} \mathrm{C}$ for $5 \mathrm{~min}$. Eight random primers were used in the present study for screening: OPA-1 (5'-CAG GCC CTT C-3'), OPA-2 (5'-TGC CGA GCT G-3'), OPA3 (5'-AGT CAG CCA C-3'), OPA-4 (5'-AAT CGG GCT G-3'), OPA-6 (5'-GGT CCC TGA C-3'), OPA-8 (5'-GTG ACG TAG G-3'), Primer-23 (5'-GTC AGG GCA A-3'), Primer-24 (5'-GGT CGG AGA A-3').

\section{Gel electrophoresis}

The amplified products were separated electrophoretically on $1 \%$ agarose gel. The gel was prepared using $1.0 \mathrm{~g}$ agarose powder containing ethidium bromide $\left(10 \mathrm{mg} \mathrm{mL}^{-1}\right) 8 \mu \mathrm{L}$ and $100 \mathrm{~mL} 1 \times \mathrm{TAE}$ buffer. Agarose gel electrophoresis was conducted in $1 \times \mathrm{TAE}$ buffer at $50 \mathrm{~V}$ and $100 \mathrm{~mA}$ for $1.5 \mathrm{~h}$. DNA ladder $(1 \mathrm{~kb})$ was electrophoresed alongside the RAPD reactions as marker. DNA bands were observed on UV-transilluminator and photographed by a gel documentation system.

\section{Scoring and data analysis}

The PCR products were analyzed after gel electrophoresis. The photographs were critically discussed on the basis of presence (1) or absence (0), size of bands and overall polymorphism of bands. These were carried out for further investigation. The scores obtained using all primers in the RAPD analysis were then pooled for constructing a single data matrix (Nei 1972).
Results and discussion

\section{Karyotype analysis}

All the samples of Ipomoea aquatica were found to possess $2 n=30$ chromosomes. The 30 chromosomes were metacentric (figure not shown). The total length of $2 n$ chromosome complements and individual chromosome length were almost similar in all the samples. No gradual decrease in the chromosomal length was observed (Table 1). However, a number of variations among the sample and control were found after staining with CMA and DAPI.

The control and samples collected from pesticideaffected areas had two less fluoresced big spherical and prominent bands in the interphase nuclei and their prophase chromosomes (data not shown). On the other hand, a number of CMA positive bands were found in the interphase nuclei and prophase chromosomes in the samples collected from other four affected areas excluding pesticide affected area (data not shown). Only five metaphase chromosomes showed CMA positive bands in the control sample (Figs. 1, 13, Table 1) whereas 6-10 chromosomes showed CMA positive bands in the rest of the samples (Figs. 2-6, 14-18, Table 1). The percentage of CMA positive banded regions in the control specimen and sample plants ranged from 8.05-23.52 (Table 1). The banding patterns of the control and affected samples were remarkably different. This result indicated the probable effect of heavy metals on the distribution of GC-repetitive sequences (Nahar and Alam 2015).

On the other hand, DAPI positive bands were found in every sample of Ipomoea aquatica collected from different affected areas as well as the control samples (Figs. 7-12, 19-24). The highest number of AT-rich regions was found in samples collected from the pesticide waste affected area followed by samples collected from the tannery effluent affected area (Figs. 9, 10, 21, 22 arrow, Table 1). In the control plant, six DAPI positive bands were found with $9.37 \%$ of AT-rich region (Figs. 7, 19, arrow, Table 1). Only four DAPI positive bands were found in plant samples collected from textile and ceramics effluent affected areas with AT-rich percent- 
ages of 8.41 and 7.34, respectively (Figs. 8, 20, 11, 23 and Table 1). In the latter two samples, the band size was bigger than the control. This indicates the probable occurrence of tandem fusion of AT-rich regions, with a decreased number of bands and larger bands compared to the control sample. Only two DAPI bands were found in the sample collected from the pharmaceutical waste affected area with $4.51 \%$ of AT-rich regions (Figs. 12, 24 arrow, Table 1). This result revealed the deletion of AT rich regions from the respective chromosomes.

\section{Heteromorphicity in chromosome banding}

In samples collected from the tannery waste affected area, one terminal CMA positive band was found in pair I and a DAPI interstitial band in pair XII. However, no such bands were found in their homologue members (Figs. 4, 16, 10, 22 arrow). The absence of bands (CMA and DAPI) in the members of homologue pairs revealed the probable deletion of the banded portion from the respective chromosomes (Hashimoto 1987, Alam et al. 1993, Begum and Alam 2005). Moreover, smaller size of the respective homologue members supported deletion of the segment from the terminal regions.

It may be noted that the heteromorphicity of the banding patterns was found in the samples collected from the tannery waste affected area where uptake of heavy metals by this species was increased (Nahar and Alam 2015). Therefore, the excessive heavy metals might cause chromosomal deletion.

\section{Marker chromosomes}

One thick and prominent centromeric DAPI band was found in a member of pair XII of samples collected from the tannery effluent affected area (Figs. 10, 22 arrow head). In the control plant of the same species, a chromosome of pair XI had two dot-like centromeric DAPI bands (Figs. 7, 19 arrow). The above chromosomes were unique with respect to banding patterns since this type of banding is absent in any chromosome of other samples. Therefore, these chromosomes could be used as marker chromosomes for these specimens.

\section{RAPD analysis}

Eight different primers were used in the RAPD analysis of six plant samples of Ipomoea aquatica Forssk. to determine the polymorphism of DNA fragments. No band was found in the primer OPA-8 (Fig. 30).

Common bands of different sizes were observed in the six samples with four primer combinations (OPA 1, OPA 2, OPA 3, and OPA 4, Figs. 25-28). The differently-sized common bands indicated the sharing of similar DNA fragments.

Besides the common bands, the control and sample specimen showed different banding patterns (Figs. 2532 ). With primer OPA-2, a band of $1600 \mathrm{bp}$ was found in textile, pharmaceutical, and ceramic waste affected samples, which was absent from the rest of the samples including controls (Fig. 26). A band of $3000 \mathrm{bp}$ was found only in samples collected from the pharmaceutical waste affected area with OPA-4 (Fig. 28). Samples collected from pharmaceutical, ceramic, and tannery affected areas had a band of $11000 \mathrm{bp}$ which was absent in other samples including control (Fig. 29). With primer-24, a light band of $1500 \mathrm{bp}$ was present only in control samples (Fig. 32).

The above results indicated that some bands were absent in the samples collected from different affected areas that were present in controls. On the other hand, a few unique fragments were found in the sample plants collected from different affected areas that were absent in controls (Fig. 29). The RAPD analysis showed a polymorphism regarding the absence and presence of DNA fragments in comparison to the control and other affected samples. In fluorescent banding, deletion and tandem duplication of chromosomal segments were found in the samples collected from different affected areas. The absence and appearance of certain unique RAPD bands may be correlated with deletion and tandem duplication of chromosomal parts.

The foregoing discussion revealed that the affected samples showed remarkable differences regarding fluorescent karyotype features and RAPD analysis in comparison to control specimens. This indicated that the industrial waste might have some devastating effect on chromosomes and DNA. Therefore, consumers must be careful about the source of these vegetables before use.

\section{References}

Ahmed, A. U. and Reazuddin 2000. Industrial Pollution of Water Systems in Bangladesh. University Press Limited, Dhaka. pp. $175-178$.

Alam, Sk. S., Jahan, N., Habib, M. A. and Islam, M. N. 2012. Cytogenetical and molecular characterization of five commercial varieties in Trichosanthes anguina L. Cytologia 77: 155-162.

Alam, Sk. S., Kondo, K. and Tanaka, R. 1993. A chromosome study of eight orchid species in Bangladesh. La Kromosomo II 71-72: 2456-2464.

Begum, R. and Alam, Sk. S. 2005. Karyotype analysis of seven orchid species from Bangladesh. Bangladesh J. Bot. 34: 31-36.

Chhatwal, G. R., Mehra, M. C., Staka, M., Katyal, M. and Nagahiru, T. 1992. Water pollution. In: Encyclopedia of Environmental Agricultural Pollution and Its Control. Anmol Publications, New Delhi. pp. 70-254.

DoE (Department of Environment) 1997. Bangladesh Gazette, No. DA-1. Dept. Environ. Ministry of Forest 1324-1327.

Doyle, J. J. and Doyle, J. L. 1987. A rapid DNA isolation procedure from small quantities of fresh leaf tissues. Phytochem. Bull. 19: $11-15$.

Glanze 1996. Heavy metal toxicity. International occupational safety and health information centre.

Hagiwara, T. 1977. Genes and linkage map of Japanese morning glory. In: Kihara, H. and Yamaguchi, H. (eds.). Plant Genetics. Shokado, Tokyo. pp. 482-501.

Hashimoto, K. 1987. Karyomorphological studies of some eighty taxa of Dendrobium. Orchidaceae. Bull. Hiroshima Bot. Gard. 
9: $1-186$.

Huq, I. S. M., Islam, N. M. and Dus, M. 2000. Effect of automobile exhausts on nutritional status of soil and plant. Bangladesh J. Soil Sci. 26: 103-111.

Huq, I. S. M., Shigenao, K., Kashem, A. M. and Singh, R. B. 2008. Cadmium phytoextraction efficiency of Arum (Colocasia antiquorum), Radish (Raphanus sativus L.) and water spinach (Ipomoea aquatica) grown in hydrophonics. Water Air Soil Pollut. 192: 273-279.

Huq, S., Ara, H., Hassan, A. and Alam, Sk. S. 2007. Comparative karyotype analysis of Typhonium trilobatum L. and its two morphological forms. Cytologia 72: 233-238.

Jahan, I., Habib, A., Alam, N. and Alam, Sk. S. 2012. Karyotype and RAPD analysis in 3 commercial varieties of Cucurbita maxima Duch. Cytologia 77: 149-154.

Joardar, J. C., Rashid, M. H. and Huq, I. S. M. 2005. Adsorption of lead $(\mathrm{Pb})$ by soil and their clay fraction. J. Asiat. Soc. Bangladesh Sci. 31: 63-74.

Kennard, W. C., Poetter, K., Dijkhuizen, A., Meglic, V., Stacls, J. E. and Havey, M. J. 1994. Linkages among RFLP, RAPD, isozymes, disease resistance and morphological markers in narrow and wide crosses of cucumber. Theor. Appl. Genet. 89: 42-48.

Nahar, K. K. and Alam, Sk. S. 2015. Physical and chemical parameters and trace metal flux in water, soil and plant samples collected from industrial effluent affected areas in and around Dhaka city. Bangladesh J. Bot. 44: 237-244.

Nakajima, G. 1963. Karyotype of genus Ipomoea. Cytologia 28: 351-359.

Nei, M. 1972. Genetic distance between populations. Am. Nat. 106: 283-292.

Schweizer, D. 1976. Reverse fluorescent chromosome banding with Chromomycin and DAPI. Chromosoma 58: 307-324. 